- the actions of corporate greenmailers are formally legitimate, but may be qualified as abuse of law.

In the United States, greenmail is interpreted differently in individual states, but what is common is that greenmail is an abuse of rights and may cause harm to the company and its members.

There is no definition of greenmail at the legislative level in Ukraine. This is due to the fact that in Ukraine the phenomenon of greenmail due to the lack of development of corporate relations in comparison with the United States has not yet become widespread, however, it should not be ruled out the significant spread of greenmail in the future.

The conclusions of the analysis include recommendations to prevent greenmail.

Key words: corporate relations, greenmail, the subject of economic activity, participants of the subject of economic activity.

DOI: 10.36695/2219-5521.1.2020.40

УДК 342.6:614.3

\title{
I.C. ДЕМЧЕНКО
}

Іван Сергійович Демченко, кандидат юридичних наук, викладач Національного медичного університету імені О.О. Богомольия*

ORCID: 0000-0001-8721-2775

\section{ІНСТИТУЦІЙНА СПРОМОЖНІСТЬ ЗАХИСТУ ВІД ІНФЕКЦІЙНИХ ЗАХВОРЮВАНЬ В УКРАЇНІ}

Постановка проблеми. За останні роки в Україні було розпочато процес реформування за різними напрямами: децентралізація або реформа системи місцевого самоврядування; антикорупційна; реформування правоохоронних органів; судова реформа; освітня; пенсійна; земельна; медична реформа тощо. Деякі 3 реформ виявились доволі успішними та дали очікуваний результат. Однак є реформи, процес впровадження яких супроводжується серйозними викликами та непередбачуваними обставинами. Однією з таких реформ $€$ медична реформа, а саме реформа санітарно-епідеміологічного нагляду та захисту населення від інфекційних хвороб.

За оціночними даними, до 5 відсотків населення країни інфіковано вірусним гепатитом C та $1-2,5$ відсотка - вірусним гепатитом В ${ }^{1}$. Україна залишається лідером у Європі за масштабами поширення ВІЛ-інфекції. За оцінками експертів UNAIDS, в Україні з ВIЛ-інфекцією живе близько 240 тис. осіб. I тільки кожен другий знає про свій діагноз - станом на 1жовтня 2019 р. на обліку в Україні перебуває 136849 ВІЛ-позитивних пацієнтів ${ }^{2}$. За даними Всесвітньої організації охорони здоров'я (далі - ВООЗ), протягом січня-листопада 2019 р. в Україні зафіксовано більше 57 тис. випадків захворювання на кір, що становить половину від усіх випадків у Європейському регіоні 3 . За оціночними даними ВООЗ, щороку в Україні близько 36000 осіб хворіють на туберкульоз. Крім того, Україна входить до десяти країн з найвищим показником поширеності мультирезистентного туберкульозу. Серед вперше діагностованих осіб майже у 29 відсотків діагностується стійкість до протитуберкульозних препаратів. Той факт, що в Україні щороку своєчасно не виявляють близько чверті випадків захворювання на туберкульоз, тільки сприяє подальшому його поширенню серед населення4. За інформацією Міністерства охорони здоров'я України (далі - MO3 України), у 2019 р., порівняно 3 попередніми роками, в Україні збільшилась кількість підтверджених випадків дифтерії5. Новий коронарівус (офіційна назва - COVID-19) за перші два місяці 2020 р., спричинив зараження більш ніж 98 тис. осіб, з яких понад 3 тис. померлиб. На момент написання даної статті в Україні є підтверджені випадки COVID-19. Очевидно, що слід очікувати як зростання захворюваності, так і летальні випадки. Маємо надію, що ситуація буде під контролем відповідних інституцій. Саме про спроможність, насамперед державних інституцій, $\mathrm{i}$ буде йтися у даному дослідженні. Однак зазначаємо, що ситуація з захворюваністю через COVID-19 може суттєво змінитися протягом кількох днів.

Постає загальне питання - чому це трапилось? Чому в Україні показники поширеності ряду інфекційних захворювань значно вищі за показники сусідніх країн? Чому ситуація з COVID-19 викликає панічні настрої у суспільстві (ситуації у Нових Санжарах та Чернівцях)? Безумовно, поширеність ряду інфекційних захворювань напряму залежить від вакцинації населення та доступу до лікарських засобів. Ці питання залишимо поза увагою даного дослідження. У цій статті ми зосередимо увагу на проблематиці інституційної спроможності захисту від інфекційних захворювань та загалом питанні санітарно-епідемічного нагляду в Україні.

Аналіз останніх досліджень і публікацій. Питання захисту від інфекційних хвороб в Україні розглядається насамперед у роботах медичного профілю. Разом із тим слід виділити низку досліджень, що акцентують увагу на тих чи інших аспектах організації діяльності санітарно-епідеміологічних служб, центрів громадського здоров'я, нормативно-правового регулювання санітарно-епідеміологічних заходів. Значна кількість публікацій присвячена тематиці протидії епідемії ВІЛ/СНІДу в Україні, нормативно-правовим аспектам та питанням прав людини, здійсненню санітарно-епідеміологічного нагляду тощо. Серед авторів, які досліджували зазначені питання, та які пов'язані 3 темою нашого дослідження, слід відмітити роботи

(C) І.С. Демченко, 2020

* Ivan Demchenko, Ph.D. in Law, Lecturer of Bogomolets National Medical University 
Є.Н. Белей, Г.О. Слабкого, І.С. Миронюка, Н.М. Нізової, В.В. Шафранського та інших вчених, представників юридичних наук, соціальної медицини, епідеміології.

Формулювання мети статті (постановка завдання). Метою даної статті є дослідити інституційну спроможність захисту населення України від інфекційних захворювань та здійснення функцій з реалізації державної політики у цій сфері.

Виклад основного матеріалу. Національне законодавство України містить досить серйозну «інституційну» проблему: щодо повноважень центральних органів виконавчої влади (далі - ЦОВВ) у сфері санітарного та епідемічного благополуччя населення та щодо захисту населення від інфекційних хвороб. Для характеристики зазначених проблем можливо вжити термін «колізії», під яким розуміємо «...розбіжності змісту двох і більше чинних законодавчих актів, прийнятих 3 того самого питання» ${ }^{\text {aбо } ~ « . . . . ~ р о з х о д ж е н н я ~ ч и ~ с у п е-~}$ речність між окремими нормативно-правовими актами, що регулюють одні й ті самі або суміжні суспільні відносини...» ${ }^{8}$. Першочерговим $\epsilon$ визначення нормативної основи щодо державного регулювання у сфері захисту населення від інфекційних хвороб та забезпечення санітарно-епідемічного благополуччя населення. Разом із визначенням нормативної основи ми будемо вказувати на існуючи прогалини та неузгодженості у діючому законодавстві України, насамперед щодо інституційної спроможності.

Згідно зі ст. 49 Конституції України держава забезпечує санітарно-епідеміологічне благополуччя. Основними законодавчими актами, що регулюють відносини у сфері забезпечення санітарного та епідемічного благополуччя населення та захисту населення від інфекційних хвороб, є, відповідно: Закони України «Про забезпечення санітарного та епідемічного благополуччя населення» та «Про захист населення від інфекційних хвороб», «Про протидію захворювання на туберкульоз», «Про запобігання захворюванню на синдром набутого імунодефіциту (СНІД) та соціальний захист населення».

Закон України «Про забезпечення санітарного та епідемічного благополуччя населення» чітко регулює діяльність 3 державного-санітарного епідеміологічного нагляду, який здійснюється органами та організаціями, що належать до системи державної санітарно-епідеміологічної служби.

Закон України «Про захист населення від інфекційних хвороб» визначає повноваження ЦОВВ щодо захисту населення від інфекційних хвороб9. За змістом даної статті йдеться про три (SIC!!!) ЦОВВ:

(1) ЦОВВ, що забезпечує формування державної політики у сфері охорони здоров'я, щодо захисту населення від інфекційних хвороб;

(2) ЦОВВ, що реалізує державну політику у сфері охорони здоров'я, щодо захисту населення від інфекційних хвороб;

(3) ЦОВВ, що реалізує державну політику у сфері санітарного та епідемічного благополуччя населення, щодо захисту населення від інфекційних хвороб.

Про які ЦОВВ йдеться в даній статті? ЦОВВ, що забезпечує формування державної політики у сфері охорони здоров'я, щодо захисту населення від інфекційних хвороб є МО3 України. Відповідно до Положення про Міністерство охорони здоров'я України, МОЗ України є головним органом у системі ЦОВВ, «...що забезпечує формування та реалізує державну політику у сфері охорони здоров'я, а також захисту населення від інфекційних хвороб... забезпечує формування та реалізує державну політику у сферах: епідеміологічного нагляду (спостереження) ... реагування на небезпеки для здоров'я та надзвичайні стани в сфері охорони здоров'я, а також забезпечення формування державної політики у сферах санітарного та епідемічного благополуччя населення» ${ }^{10}$. Якщо виходити із положень даної норми, то можливо зробити наступні висновки:

1. МОЗ України $є$ ЦОВВ, що забезпечує як формування, так і реалізацію державної політики щодо захисту населення від інфекційних хвороб. Також МОЗ України забезпечує формування державної політики у сферах санітарного та епідемічного благополуччя населення.

2. Що це за ЦОВВ, який реалізує державну політику у сфері санітарного та епідемічного благополуччя населення, щодо захисту населення від інфекційних хвороб?

Відповідь на це питання можливо знайти у ст. 31 Закону України «Про забезпечення санітарного та епідемічного благополуччя населення». Вже зазначену систему державної санітарно-епідемічної служби України становлять: ЦОВВ, що реалізує державну політику у сфері санітарного та епідемічного благополуччя населення. Таким ЦОВВ була Державна санітарно-епідеміологічна служба України (далі - Державна СЕС України).

У процесі оптимізації системи ЦОВВ Кабінетом Міністрів України було прийнято рішення про утворення Державної служби України з питань безпечності харчових продуктів та захисту прав споживачів (надалі - Держпродспоживслужба), реорганізувавши шляхом перетворення Державної СЕС11 (редакція від 10 вересня 2014 р.), та фактично приєднання до новоствореної Держпродспоживслужби.

Рішення щодо зазначеної реорганізації Державної СЕС оскаржувалось у судовому порядку (справа пройшла першу та апеляційну інстанцію і Вищим адміністративним судом України була направлена до суду першої інстанції на новий розгляд ${ }^{12}$ ). Справа пройшла нове коло, від суду першої інстанції до суду касаційної інстанції. Завершенням розгляду даної справи стало рішення Київського апеляційного адміністративного суду від 8 лютого 2016 р.13 (із змінами та доповненнями), відповідно до якого рішення Кабінету Міністрів України в частині реорганізації Державної СЕС України було визнано протиправним та скасовано.

У 2017 р. Кабінет Міністрів України відміняє своє рішення про реорганізацію Державної СЕС шляхом iii приєднання до Держпродспоживслужби. Натомість приймається рішення про ліквідацію Державної санітарно-епідеміологічної служби ${ }^{14}$. Дане рішення Кабінету Міністрів України знову було оскаржено у суді. Справа пройшла усі три інстанції (оскаржувалась в Окружному адміністративному суді міста Києва 15 ; в суді апеляційної інстанції - Шостий апеляційний адміністративний суд16; Верховному Суді, Касаційному адміністративному суді17). Підсумок: у задоволенні адміністративного позову було відмовлено. Тобто рішення про ліквідацію Державної СЕС залишилось у силі. 
При цьому звертаємо увагу на позицію суддів Верховного Суду стосовно зазначеного положення ст. 31 Закону України «Про забезпечення санітарного та епідемічного благополуччя населення», які зазначили: «...мова йде про обов'язковість існування в системі державної санітарно-епідеміологічної служби Украӥни иентрального органу виконавчої влади, щзо реалізує держсавну політику у сфері санітарного та епідемічного благополуччя населення, але не про точне найменування иього органу» 18 . Якщо розглядати положення Закону України «Про забезпечення санітарного та епідемічного благополуччя населення», то дійсно ч. 1 ст. 31 Закону України «Про забезпечення санітарного та епідемічного благополуччя населення» не містить найменування ЦОВВ, що реалізує державну політику у сфері санітарного та епідемічного благополуччя населення, однак, вже ч. 2 зазначеної статті та, власне, положення Розділів IV та V регламентують діяльність саме Державної СЕС України. Чи не мав би Верховний Суд засовувати принцип комплексності (закон має тлумачитись як єдиний акт, тобто окремі його положення не можуть бути витлумачені окремо, або в межах статті чи розділу, вони мають розглядатись у комплексі19) тлумачення норм права?

Висловлюємо наступну думку. Верховний Суд (як власне і суди першої та апеляційної інстанції), розглядаючи вищенаведені справи, досліджували питання протиправності (акцент на порушенні матеріальних і процесуальних норм) дій Кабінету Міністрів України при прийнятті зазначеної постанови, а не питання того, чи призведе прийняття цієї постанови щодо ліквідації Державної СЕС до порушення вимог законодавчих актів, що регулюють відносини у сфері забезпечення санітарного та епідемічного благополуччя населення та захисту населення від інфекційних хвороб. І дійсно, якщо розглядати питання з точки зору протиправності/правомірності дій (прийняття рішень) Кабінетом Міністрів України, то останній діяв у повній відповідності до вимог як Конституції України (ст. ст. 19, 113, 116, 117), так і чинного законодавства України (ст. ст. 20, 49 Закону України «Про Кабінет Міністрів України», ст. 5 Закону України «Про центральні органи виконавчої влади»). Державна СЕС України була de-jure та, власне, de-facto, ліквідована у чіткій відповідності до вимог законодавства.

Однак, якщо вже Державна СЕС України була ліквідована, то повноваження щодо реалізації державної політики у сфері санітарного та епідемічного благополуччя населення лишились. Більше того, нами ще не було надано відповідь на питання: якому ЦОВВ належать або були передані зазначені повноваження.

Якщо простежити історію передачі повноважень Державної СЕС України (на основі історії змін, що вносились до постанови Кабінету Міністрів України № 442 від 10 вересня 2014 р.), то вона буде наступною:

1) 10 вересня 2014 р. - функції з реалізації державної політики, які належали Державній СЕС, були покладені на Держпродспоживслужбу (у цей самий час почалося судове оскарження реорганізації Державної CEC);

2) 5 серпня 2015 р. - функції з реалізації державної політики, які належали Державній СЕС, покладені на Держпродспоживслужбу, крім функцій у сфері епідемічного нагляду (спостереження). Функції у сфері епідемічного нагляду (спостереження) покладаються на МО3 України 20 (судове оскарження - триває);

3) 14 липня 2016 р. набрала законної сили ухвала Вищого адміністративного суду України - щодо залишення без змін рішення Київського апеляційного адміністративного суду від 8 лютого 2016 р. про визнання протиправним та скасування абз. 2 п. 1 постанови Кабінету Міністрів України від 10 вересня 2014 р. № 442 «Про оптимізацію системи центральних органів виконавчої влади» в частині реорганізації Державної санітарно-епідеміологічної служби України;

4) 29 березня 2017 р. Кабінет Міністрів України ліквідував СЕС, повторивши своє рішення щодо передачі повноважень до Держпродспоживслужби, крім функцій у сфері епідемічного нагляду (спостереження).

Скасування акта застосовується тоді, коли спірний акт не породжує жодних правових наслідків від моменту прийняття такого акта 21 . Виникає питання, чи призводить скасування акта (абз. 2 п. 1 постанови Кабінету Міністрів України від 10 вересня 2014 р. № 442 в частині реорганізації Державної санітарно-епідеміологічної служби України) до скасування акта щодо передачі функцій у сфері епідемічного нагляду (спостереження) до МО3 України (постанови Кабінету Міністрів України № 591 від 5 серпня 2015 р.22)? 3 огляду на положення п. 1 частини другої ст. 162 КАС України у разі визнання акта незаконним суд повинен скасувати його, якщо він є актом індивідуальної дії, або визнати нечинним, якщо він $є$ нормативно-правовим актом 23 . Суд застосував такий спосіб захисту порушеного акта, як «скасування», тому що оскаржуваний акт $\epsilon$ актом індивідуальної дії - немає загальних правил регулювання однотипних відносин, що розраховані на тривале застосування, а містить положення, які розраховані на одноразове застосування, і вони вичерпуються фактом їх виконання. А оскільки передача функцій у сфері епідемічного нагляду (спостереження) до МО3 України (постанова Кабінету Міністрів України № 591 від 5 серпня 2015 р.) не оскаржувалася, то це дає підстави стверджувати, що передача функцій у сфері епідемічного нагляду (спостереження) до МОЗ України була здійснена правомірно. I саме 35 серпня 2015 р. функції у сфері епідемічного нагляду (спостереження) покладено на МОЗ України.

Відповідно до вже згаданої постанови Кабінету Міністрів України № 348 від 29 березня 2017 р. саме на Держпродспоживслужбу були покладені завдання і функції з реалізації державної політики у сфері санітарного та епідемічного благополуччя населення та із здійснення контролю (нагляду) за дотриманням вимог санітарного законодавства (крім функцій з реалізації державної політики у сфері епідеміологічного нагляду (спостереження $)^{24}$, які, як також зазначено вище, були передані до МОЗ України).

Начебто, ситуація стає більш-менш зрозуміло - Держпродспоживслужба здійснює завдання і функції колишньої Державної СЕС, крім функцій у сфері епідеміологічного нагляду (спостереження).

Що є епідеміологічним наглядом? Якщо прискіпливо проаналізувати чинне законодавство, то поняття епідеміологічного нагляду, принаймні на законодавчому рівні, не закріплено. Хоча даний термін широко застосовується у підзаконних нормативно-правових актах. Наприклад: «Про затвердження тимчасових мето- 
дичних рекомендацій «Епідеміологічний нагляд і контроль за випадками пташиного грипу у людей»25; Перелік інфекційних захворювань, які мають прогресивно/поступово охоплюватися епідеміологічним наглядом ${ }^{26}$; Порядок проведення епідеміологічного нагляду за кором, краснухою та синдромом вродженої краснухи ${ }^{27}$; Порядок організації проведення епідеміологічного нагляду за грипом та гострими респіраторними вірусними інфекціями, заходів з готовності в міжепідемічний період і реагування під час епідемічного сезону захворюваності на грип та ГРВІ28 та чимало інших.

Термін «епідеміологічний нагляд» «потрапив» до вітчизняного законодавства через процес виконання заходів з імплементації Угоди про асоціацію між Україною, з однієї сторони, та Свропейським Союзом, Європейським Співтовариством з атомної енергії і їхніми державами-членами, з іншої сторони. Україна мала долучитися до мережі епідемічного нагляду та контролю за поширенням інфекційних захворювань. При цьому термін «епідеміологічний нагляд» означає систематичний збір, реєстрацію, аналіз, тлумачення i поширення даних та аналізів інфекційних захворювань, а також пов'язаних спеціальних питань у сфері охорони здоров'я» ${ }^{29}$. В Україні на рівні закону пропонувався фактично аналогічний термін: «епідеміологічний нагляд - систематичний збір, зберігання, систематизація, аналіз та поширення даних про стан здоров'я та рівень захворюваності, благополуччя населення і показники середовища життєдіяльності». Однак відповідний Проект Закону України «Про внесення до Закону України «Про забезпечення санітарного та епідемічного благополуччя населення» (реєстр. номер 8464) ${ }^{30}$ так і не був розглянутий Верховною Радою України.

Натомість у вітчизняному законодавстві закріплений та детально регламентований у підзаконних нормативно-правових актах «державний санітарно-епідеміологічний нагляд». Так, «державний санітарно-епідеміологічний нагляд - це діяльність органів державної санітарно-епідеміологічної служби по контролю за дотриманням юридичними та фізичними особами санітарного законодавства 3 метою попередження, виявлення, зменшення або усунення шкідливого впливу небезпечних факторів на здоров'я людей та по застосуванню заходів правового характеру щодо порушників» ${ }^{31}$. Положення про державний санітарно-епідеміологічний нагляд в Україні 32 та ряд інших підзаконних нормативно-правових актів містять повноваження 3 державного санітарно-епідеміологічного нагляду, закріплені за Головним державним санітарним лікарем України, головними державними санітарними лікарями.

Так які ж повноваження функцій з реалізації державної політики у сфері епідеміологічного нагляду (спостереження) були передані МО3 України? На наш погляд - ніякі. У постанові Кабінету Міністрів України № 348 від 29 березня 2017 р. мало б йтися про «державний санітарно-епідеміологічний нагляд», а не про «функції з реалізації державної політики у сфері епідеміологічного нагляду (спостереження)». Саме це формулювання $є$ ключовою причиною колізій та проблем, що існують у сфері інституційної спроможності захисту від інфекційних захворювань.

Враховуючи вищезазначене, можемо зробити наступні висновки. По-перше, Держпродспоживслужба здійснює завдання і функції колишньої Державної СЕС. По-друге, функції у сфері епідеміологічного нагляду (спостереження) були передані МО3 України. Однак, незрозуміло, що це є за функції. Відповідаючи на питання, який ЦОВВ реалізує державну політику у сфері санітарного та епідемічного благополуччя населення - це є Держпродспоживслужба. Звернемо увагу на чинне законодавство, яке регулює повноваження Держпродспоживслужби та МО3 України.

Держпродспоживслужба. Відповідно до Положення про Державну службу України з питань безпечності харчових продуктів та захисту споживачів, Держпродспоживслужба є ЦОВВ, який реалізує державну політику у галузі санітарного законодавства, санітарного та епідемічного благополуччя населення (крім виконання функцій з реалізації державної політики у сфері епідемічного нагляду (спостереження) ${ }^{33}$. Функції та повноваження Держпродспоживслужби у галузі санітарного та епідемічного благополуччя населення, державного нагляду (контролю) за дотриманням санітарного законодавства визначені у підпункті 3 п. 4 Положення про Держпродспоживслужбу. Порівняно з повноваженнями державного санітарно-епідемічного нагляду до Закону України «Про забезпечення санітарного та епідемічного благополуччя населення», повноваження Держпродспоживслужби є доволі видозмінені та, часом, обмежені. Зокрема це, interalia:

- організація здійснення державного нагляду (контролю) щодо дотримання вимог санітарного законодавства (однак це є частина державного санітарно-епідемічного нагляду (SIC!!!) ${ }^{34}$;

- готування подання до Кабінету Міністрів України про запровадження або скасування карантинного режиму (однак це є посадові повноваження Головного державного санітарного лікаря України ${ }^{35}$;

- подання в установленому порядку пропозицій щодо обмеження або заборони в’їду на територію України її громадян, іноземців та осіб без громадянства, експорту, імпорту, транзиту вантажів і товарів 3 держав або регіонів у зв'язку з неблагополучною епідемічною ситуацією на їх території. Аналогічне повноваження має і MO3 України 36 , (відповідне рішення приймається Кабінетом Міністрів України);

- проводить державну санітарно-епідеміологічну експертизу, видає за результатами ії проведення відповідні висновки (порядок регламентується Законом України «Про забезпечення санітарного та епідемічного благополуччя населення», також це є частина державного санітарно-епідемічного нагляду (SIC!!!) ${ }^{37}$;

- здійснює у межах компетенції контроль за усуненням причин і умов виникнення та поширення інфекційних, масових неінфекційних захворювань, отруєнь та радіаційних уражень людей (напрям діяльності Державної CEC) $)^{38}$;

- розробляє та здійснює санітарні … заходи, що стосуються обмеженого (визначеного) кола осіб чи випадків, передбачених законодавством (санітарні заходи - це те саме, що й санітарні та протиепідемічні (профілактичні) заходи ${ }^{39}$ );

- бере участь у реалізації науково-технічної, технологічної та інноваційної політики, впровадженні у виробництво науково-технічних досягнень та передового досвіду 3 питань... профілактики захворювань 
людини, а також факторів середовища життєдіяльності людини (це здійснюють наукові установи гігієнічного та епідеміологічного профілю40);

- бере участь у проведенні санітарно-епідеміологічних розслідувань, спрямованих на виявлення причин та умов, що призводять до виникнення і поширення інфекційних хвороб, у тому числі через харчові продукти, групових та індивідуальних харчових отруєнь, масових неінфекційних захворювань (отруєнь) та радіаційних уражень, випадків порушення норм радіаційної безпеки, санітарних правил роботи 3 радіоактивними речовинами, іншими джерелами іонізуючих випромінювань та вживає заходів до їх усунення відповідно до законодавства (частина повноважень головних державних санітарних лікарів та інших осіб, які здійснюють державний санітарно-епідеміологічний нагляд41;

- здійснює передбачені законодавством заходи для припинення порушення санітарного законодавства (повноваження головних державних санітарних лікарів (іх заступників ${ }^{42}$ ).

Звертаємо увагу і на положення п. 7 Положення про Держпродспоживслужбу. «Керівники самостійних структурних підрозділів територіальних органів Держпродспоживслужби, на які покладено здійснення повноважень Держпродспоживслужби у сфері санітарного законодавства, санітарного та епідемічного благополуччя населення, забезпечують виконання функцій щодо затвердження та підписання передбачених законодавством документів, повноваження щодо затвердження та підписання яких належить до компетенції головних державних санітарних лікарів відповідної адміністративно-територіальної одиниці (крім виконання функцій з реалізації державної політики у сфері епідеміологічного нагляду (спостереження)...» ${ }^{43}$. Іншими словами, Держпродспоживслужба забезпечила виконання повноважень головних державних санітарних лікарів та інших осіб, які здійснюють державний санітарно-епідеміологічний нагляд.

Формально, наявна ще одна правова колізія - повноваженнями ЦОВВ, що реалізує державну політику у сфері санітарного та епідемічного благополуччя населення: 1) за законом належать Головному державному санітарному лікарю України, головним державним санітарним лікарям та іншим посадовим особам, які здійснюють державний санітарно-епідеміологічний нагляд; 2) за рядом постанов Кабінету Міністрів України зазначені повноваження належать Держпродспоживслужбі. У правовій доктрині загальновизнано, що вищістю характеризується ієрархічний принцип вирішення колізій - Lex superior derogat inferiori (вищий за юридичною силою акт скасовує дію нижчого, з того ж самого питання). У разі суперечності положень різних нормативно-правових актів, незалежно від часу їх прийняття, а також сфери дії норм, що знаходяться у колізії, слід керуватися нормою, вміщеною до акта вищої юридичної сили 44 . Але, яким чином діяти, якщо і dejure, i de-facto, Державна СЕС ліквідовано та фактично не існує?

Міністерство охорони здоров'я України. Відповідно до положення про Міністерство охорони здоров’я України, МОЗ України є головним органом у системі ЦОВВ, що... реалізує державну політику у сфері епідеміологічного нагляду (спостереження) та забезпечує формування державної політики у сферах санітарного та епідемічного благополуччя населення ${ }^{45}$. Функції та повноваження МО3 України визначені в п. 4 Положення про МО3 України.

При цьому, якщо порівняти повноваженнями ЦОВВ, що реалізує державну політику у сфері санітарного та епідемічного благополуччя населення відповідно до Закону України «Про захист населення від інфекційних захворювань» (ч. 3 ст. 6) з повноваженнями МОЗ України у сфері санітарного та епідемічного благополуччя населення, то вони майже тотожні! Тобто хоча МОЗ України є ЦОВВ, який лише формує державну політику у сфері санітарного та епідемічного благополуччя населення, однак, виходячи зі своїх повноважень MO3 України має повноваження щодо реалізації державної політики в зазначеній сфері (таблиця порівняння повноважень додається*).

Цілком погоджуюсь із констатацією С. Белей, що передача повноважень Державної СЕС відбулась неналежним чином, оскільки на нормативному рівні чітко не закріплено те, які саме повноваження цього суб'єкта публічної адміністрації і кому передані, не розмежовано відповідних повноважень МОЗ України та Державної служби з питань безпечності харчових продуктів та захисту споживачів, не внесено змін до чинних нормативних актів, якими регламентовано порядок здійснення процедур санітарно-епідеміологічного нагляду тощо 46.

Причини виникнення такої ситуації.

Відповідно до Концепції розвитку системи громадського здоров'я47 (далі - Концепція), акцентувалась увага на недоліках у діяльності Державної СЕС України. Зокрема, структура і потенціал Держсанепідслужби, іiі діяльність, які традиційно орієнтовані на профілактику та боротьбу з інфекційними хворобами шляхом регламентації факторів ризику і проведення перевірок дотримання вимог санітарного законодавства, залишилися неадаптованими до нових викликів суспільства та не відповідають сучасним підходам до епідеміологічного нагляду та зміцнення здоров'я населення. Паралельно із системою санітарно-епідеміологічної служби створено інші системи епідеміологічного нагляду за окремими інфекційними хворобами, зокрема ВІЛ-інфекцією, туберкульозом, інфекціями, що передаються статевим шляхом. Вирішення проблем передбачалось здійснити шляхом, зокрема:

- посилення ролі Міністра охорони здоров'я у сфері громадського здоров'я через запровадження принципу пріоритетності збереження здоров'я населення в усіх напрямах діяльності органів державної влади та визначення на законодавчому рівні повноважень Міністра щодо подолання загроз та наслідків надзвичайних ситуацій, які можуть мати негативний вплив на здоров'я населення;

- забезпечення функціонування Центру громадського здоров’я МОЗ як координатора програм та проєктів громадського здоров'я;

- посилення ролі МО3 як центрального органу виконавчої влади, відповідального за реалізацію державної політики у сфері громадського здоров'я (термін, щзо широко застосовується у міжнародній практицүi, однак який не знайшов свого закріплення у вітчизняному законодавстві); 
- визначення на законодавчому рівні засад державної політики у сфері громадського здоров’я та прийняття закону про систему громадського здоров'я;

- підготовку проєктів нормативно-правових актів, що регулюють питання у сфері громадського здоров'я, з метою забезпечення функціонування єдиної системи громадського здоров'я, оптимізації регуляторної політики у сфері громадського здоров'я;

- удосконалення санітарних норм і правил з урахуванням міжнародної практики та сучасних соціально-економічних умов тощо.

Станом на початок 2020 р. здійснити передбачені Концепцією заходи та досягти поставлених результатів не вдалося з різних, суб'єктивних та об'єктивних причин.

Слід також звернути увагу, що МОЗ України у межах своєї компетенції утворювало, визначало, реорганізовувало різні державні установи, заклади, діяльність яких була пов'язана з епідемічним наглядом (у тому значенні, як його розумів МО3 України. А МОЗ України розумів «епідемічний нагляд» так, як цю категорію розуміють у законодавстві Свропейського Союзу).

3-поміж інших, була утворена державна установа «Центр громадського здоров’я Міністерства охорони здоров’я України» (відповідно до Наказу МОЗ № 604 від 18 вересня 2015 р.48). Зокрема, державний заклад «Український центр з контролю та моніторингу захворювань Міністерства охорони здоров’я України» та ряд державних підприємств та установ Державної санітарно-епідеміологічної служби України (а саме: лабораторні центри) були юридичними особами, які реорганізовувалися шляхом злиття. Перелік державних підприємств, установ та організацій, що реорганізовувалися, неодноразово змінювався 49 . Статут державної установи «Центр громадського здоров'я Міністерства охорони здоров'я України» також декілька разів викладався у новій редакції.

В останній чинній на сьогоднішній день редакції Статуту Державної установи «Центр громадського здоров'я Міністерства охорони здоров'я України» ${ }^{50}$ (далі - Центр), зазначено, що дана установа є санітарнопрофілактичним закладом охорони здоров'я, головним завданням якого, з-поміж іншого, є діяльність у галузі громадського здоров'я, а саме здійснення епідемічного нагляду (спостереження), виконання повноважень щодо захисту населення від інфекційних хвороб та неінфекційних захворювань (п. 1 розділу I Статуту). Центр утворений з метою реалізації державної політики у галузі громадського здоров’я. (п. 1 розділу III Статуту). Ми вже зазначали, що не зовсім зрозуміло, що мається на увазі під «здійсненням епідемічного нагляду (спостереження) та що таке державна політика у галузі громадського здоров’я. Однак, якщо ознайомитись зі статутними завданнями Центру, то такі завдання фактично схожі на повноваження МО3 України у сфері санітарного та епідемічного благополуччя населення.

О. Проневич, досліджуючи імплементацію права СС в Україні щодо утворення Європейського центру з профілактики та контролю за захворюваннями, зазначає, що виходячи з Угоди про асоціацію та інших прийнятих нормативних документів, положень національного законодавства України, основною метою є «утворення Національного (українського) центру громадського здоров'я 51 i, фактично, його приєднання до єдиного загальноєвропейського простору громадського здоров'я. Утворення та/або формування надійної системи епіднагляду є частиною зобов'язань України в рамках процесу Євроінтеграції52. Власне, таким національним центром громадського здоров’я і є ДУ «Центр громадського здоров’я МОЗ України», однак $є$ питання щодо правомірності «передачі» повноважень щодо реалізації державної політики у сфері санітарного та епідемічного благополуччя населення як MO3 України, так і у подальшому ДУ «Центр громадського здоров'я МОЗ України».

О. Проневич, продовжуючи свої міркування, говорить про посилення інституційої спроможності ДУ «Центр громадського здоров'я МОЗ України» шляхом надання йому статусу ЦОВВ, діяльність якого спрямовується та координується МОЗ України (зумовлено особливою значущістю соціальної місії, складністю організаційної структури, комплексним характером діяльності центру та перманентною взаємодією з Свропейським центром 3 профілактики та контролю за захворюваннями) ${ }^{53}$. Дана думка $\epsilon$ слушною, однак таке рішення має прийматися не МО3 України, а Кабінетом Міністрів України (міністерства та інші центральні органи виконавчої влади утворюються, реорганізуються та ліквідуються Кабінетом Міністрів України за поданням Прем'єр-міністра України $\left.{ }^{54}\right)$.

Висновки. Інституційна спроможність захисту населення України від інфекційних захворювань та здійснення функцій з реалізації державної політики у цій сфері фактично паралізована, оскільки передача повноважень Державної СЕС відбулась неналежним чином.

На даний момент слід констатувати наступне: 1. De-jure i de-facto ліквідована Державна CEC (хоча перед надсиланням иієї статті до редакції, новий міністр охорони здоров'я озвучив тезу про відновлення державної CEC- прим. автора). 2. Частина повноважень щодо реалізації державної політики у сфері санітарного та епідемічного благополуччя передана Держпродспоживслужбі. 3. Введено у правову площину поняття «епідемічний нагляд», що не узгоджується з формально існуючою в Україні системою державного санітарно-епідеміологічного нагляду. 4. МО3 України наділено значними повноваженнями щодо реалізації державної політики у сфері санітарного та епідемічного благополуччя, які мали б належати Держпродспоживслужбі чи певному новоствореному ЦОВВ (наприклад - Центру громадського здоров’я та контролю за захворюваннями 55 ). 5. Фактично, відповідно до діючого законодавства, більша частина завдань державного санітарно-епідеміологічного нагляду, як і напрямів діяльності системи державної СЕС України, не передано жодним центральним органам виконавчої влади.

Пропонуємо наступні можливі варіанти вирішення ситуації з інституційною спроможністю щодо захисту від інфекційних захворювань: 
Верховна Рада України. Найбільш дієвим, однак таким, що потребує координованих та спільних зусиль органів державної влади, $є$ розробка та прийняття нових редакцій Законів України «Про забезпечення санітарного та епідемічного благополуччя населення» та «Про захист населення від інфекційних хвороб», чи прийняття нового Закону (навіть «Про громадське здоров'я» чи «Про систему громадського здоров'я»), що врешті-решт врегулює ситуацію у сфері забезпечення санітарного та епідемічного благополуччя населення та захисту від інфекційних хвороб та урегулює існуючі розбіжності між нормативно-правовим регулюванням de jure та de facto.

Кабінет Міністрів України. Перший варіант - передача повноважень щодо реалізації державної політики у сфері санітарного та епідемічного благополуччя у повному обсязі до Держпродспоживслужби (включаючи державний санітарно-епідемічний нагляд); Другий варіант - передача до МОЗ України функцій державного санітарно-епідемічного нагляду замість «незрозуміло яких» функцій з епідемічного нагляду; Третій варіант - відновлення державної СЕС чи утворення нового ЦОВВ з повноваженнями щодо захисту населення від інфекційних захворювань.

Таблиця порівняння повноважень ЦОВВ, що реалізус державну політику у сфері

Додаток санітарного та епідемічного благополуччя населення та МОЗ Украйни

Повноваження ЦОВВ, що реалізус державну полі-
тику у сфері санітарного та епідемічного благопо-
луччя населення відповідно до Закону України
«Про захист населення від інфекційних захворю-
вань» (ч. 3 ст. 6)

розробляе санітарні норми, методи профілактики інфекційних хвороб, інші нормативно-правові акти;

здійснює нагляд за додержанням підприємствами, установами, організаціями незалежно від форми власності та громадянами законодавства у сфері захисту населення від інфекційних хвороб, контролює виконання вимог санітарно-протиепідемічних правил і норм;

здійснює епідеміологічний нагляд за побічною дією імунобіологічних препаратів та їх епідеміологічною ефективністю;

веде державний облік інфекційних хвороб;

координує проведення закладами охорони здоров'я, органами державної санітарно-епідеміологічної служби, науково-дослідними установами, що належать до сфери його управління, заходів, спрямованих на санітарну охорону території України;

аналізує і прогнозує епідемічну ситуацію в Україні та в окремих регіонах, розробляє та подає в установленому порядку обгрунтовані пропозиції, спрямовані на профілактику та зниження рівня інфекційних хвороб, на поліпшення епідемічної ситуації;

організовує проведення наукових досліджень, спрямованих на зниження рівня інфекційних хвороб, поліпшення епідемічної ситуації, підвищення ефективності протиепідемічних заходів;
Функції та повноваження МОЗ України відповідно до Положення про Міністерство охорони здоров'я України (п.п. 14, п. 4)

затверджує державні санітарні норми і правила, санітарно-епідеміологічні та санітарно-протиепідемічні правила і норми, санітарно-епідеміологічні правила i норми, протиепідемічні правила і норми, гігієнічні та протиепідемічні правила і норми, державні санітарноепідеміологічні нормативи, санітарні регламенти;

МОЗ України не отримало цих функцій - вони відійшли до Держпродспоживслужби, яка: організовує державний нагляд (контроль) щодо дотримання вимог санітарного законодавства;здійснює державний нагляд за додержанням підприємствами, установами, організаціями всіх форм власності та громадянами державних санітарних норм і правил...;здійснює санітарні заходи щодо охорони території України шляхом проведення державного санітарно-епідеміологічного нагляду (контролю) за дотриманням санітарного законодавства, медико-санітарного контролю (огляду) з метою запобігання в'їзду на територію України транспортних засобів, ввезенню вантажів, товарів та інших предметів, у тому числі лікарських засобів, біологічних, хімічних і радіоактивних речовин, а також матеріалів і відходів, що можуть створювати небезпеку для життя і здоров'я населення (крім заходів, пов'язаних із здійсненням медико-санітарного спостереження (епідеміологічного нагляду (спостереження)...56, п.п. 3, п. 4

Фактично належить до фармаконагляду, що належить до повноважень МО3 України.

ведення державного обліку інфекційних $і$ професійних захворювань, отруєнь;

координує проведення закладами охорони здоров'я, науково-дослідними установами, що належать до сфери його управління, заходів, спрямованих на санітарну охорону території України;

аналізує і прогнозує епідемічну ситуацію та показники здоров'я населення в Україні та в окремих регіонах, розробляє і забезпечує здійснення заходів, спрямованих на профілактику та зниження рівня інфекційних хвороб, на поліпшення епідемічної ситуації;

координує проведення наукових досліджень, спрямованих на зниження рівня захворюваності населення, поліпшення епідемічної ситуації, підвищення ефективності протиепідемічних заходів; 
організовує проведення наукових досліджень, спрямованих на зниження рівня інфекційних хвороб, поліпшення епідемічної ситуації, підвищення ефективності протиепідемічних заходів;

забезпечує створення, зберігання та своєчасне оновлення необхідного запасу дезінфекційних засобів на випадок епідемій;

здійснює міжвідомчу координацію та забезпечує взаємодію 3 іншими центральними та місцевими органами виконавчої влади у сфері захисту населення від інфекційних хвороб;

погоджує проєкти рішень, якими встановлюється поря-
док проведення профілактичних і протиепідемічних заходів;

погоджує порядок проведення профілактичних і про-

тиепідемічних заходів у межах підпорядкованих

ЦОВВ, що реалізують державну політику у сферах оборони і військового будівництва, охорони громадського порядку, захисту державного кордону, виконання кримінальних покарань, Службі безпеки України, територій, об'єктів, частин і підрозділів;

організовує та координує роботи з проведення гігієнічного навчання населення 3 питань запобігання виникненню та поширенню інфекційних хвороб, а також забезпечує медичні служби міністерств, інших центральних і місцевих органів виконавчої влади, органи державної санітарно-епідеміологічної служби періодичною інформацією про епідемічну ситуацію в Україні та у світі, щорічно інформує їх про прийняті санітарнопротиепідемічні правила та інші нормативно-правові акти у сфері захисту населення від інфекційних хвороб. координує проведення наукових досліджень, спрямованих на зниження рівня захворюваності населення, поліпшення епідемічної ситуації, підвищення ефективності протиепідемічних заходів;

здійснює міжвідомчу координацію і забезпечує взаємодію з іншими центральними та місцевими органами виконавчої влади у сфері захисту населення від інфекційних хвороб..

$-$

здійснюе міжвідомчу координачію $i$ забезпечує взаємодію з іншими центральними та місиевими органами виконавчої влади у сфері захисту населення від інфекційних хвороб та неінфекційних захворювань;

координує роботу з проведення гігієнічного навчання населення з питань запобігання виникненню та поширенню інфекційних хвороб, поширює інформацію про епідемічну ситуацію в Украйні та у світі.

1 Державна стратегія у сфері протидії ВІЛ-інфекції/СНІДу, туберкульозу та вірусним гепатитам на період до 2030 року: схвалено розпорядженням Кабінету Міністрів України № 1415-р від 27 листопада 2019 р. Офіиійний вісник Украӥни. 2020. № 10. С. 220. Ст. 404, код акта 97777/2020

2 СНIД в Україні: статистика на 01.11.2019 p. URL: http://www.antiaids.org/ukr/news/aids stat/snd-v-ukran-statistika-na01112019-11352.html (дата звернення: 06.03.2020).

3 Strengthening response to measles outbreak in Ukraine. URL: http://www.euro.who.int/en/countries/ukraine/news/news/2020/ 01/strengthening-response-to-measles-outbreak-in-ukraine (дата звернення: 06.03.2020).

4 Державна стратегія у сфері протидії ВІЛ-інфекції/СНІДу, туберкульозу та вірусним гепатитам на період до 2030 року: схвалено розпорядженням Кабінету Міністрів України № 1415-р від 27 листопада 2019 р. Офіиійний вісник Украӥни. 2020. № 10. C. 220. Ст. 404

5 Оперативні дані щодо захворюваності на грип, ГРВI, кір та дифтерію. URL: https://moz.gov.ua/article/news/operativnidani-schodo-zahvorjuvanosti-na-grip-grvi-kir-ta-difteriju (дата звернення : 06.03.2020).

${ }^{6}$ Novel Coronavirus (COVID-19) Situation. URL: https://experience.arcgis.com/experience/685d0ace521648f8a5beeeee1b9125cd (дата звернення : 06.03.2020).

7 Шемшученко Ю.С. Теоретичні засади подолання колізій у законодавстві України. Колізії у законодавстві Украӥни: проблеми, теорії і практики. Київ: Генеза, 1996. С. 6-7. С. 6.

8 Матузов Н.И. Юридические коллизии и способы их разрешения. Теория государства и права: Курс лекиий / под ред. Н.И. Матузова и А.В. Малько. Москва: Юристъ, 1997. С. 424-439. С. 424.

9 Про захист населення від інфекційних хвороб: Закон України № 1645-III від 06 квітня 2000 р. (із змінами). Офіційний вісник України. 2000. № 17. Ст. 690, ст. 6.

10 Положення про Міністерство охорони здоров’я України: затверджено постановою Кабінету Міністрів України № 267 від 25 березня 2015 р. (із змінами). Офіційний вісник Украӥни. 2015. № 38. Ст. 1141. п. 1.

11 Про оптимізацію системи центральних органів виконавчої влади: постанова Кабінету Міністрів України № 442 від 10 вересня 2014 р. (у редакції від 10 вересня 2014 р.). Офіційний вісник України. 2014. № 74. Ст. 2105. п.1.

12 Ухвала Вищого адміністративного суду України від 23 вересня 2015 р. у справі K/800/29033/15. URL: http://www.reyestr. court.gov.ua/Review/51722433 (дата звернення: 06.03.2020).

13 Постанова Київського апеляційного адміністративного суду від 08 лютого 2016 р. у справі 826/19610/14. Oфiųiŭний вісник України. 2016. № 32. URL: http://www.reyestr.court.gov.ua/Review/55797697 (дата звернення : 06.03.2020).

14 Деякі питання Державної санітарно-епідеміологічної служби: постанова Кабінету Міністрів України № 348 від 29 березня 2017 р. Офіиійиий вісник Украӥни. 2017. № 43. Ст. 1329.

15 Рішення Окружного адміністративного суду м. Києва від 11 вересня 2018 р. у справі 826/9285/17. URL: http://www.reyestr. court.gov.ua/Review/76904381 (дата звернення : 06.03.2020).

16 Постанова Шостого Апеляційного адміністративного суду від 04 грудня 2018 р. у справі 826/9285/17. URL: http://www. reyestr.court.gov.ua/Review/78467805 (дата звернення : 06.03.2020).

17 Постанова Верховного Суду. Касаційного адміністративного суду від 11 грудня 2019 р. у справі № 826/9285/17. URL: http://www.reyestr.court.gov.ua/Review/86305757 (дата звернення : 06.03.2020). 
18 Постанова Верховного Суду. Касаційного адміністративного суду від 11 грудня 2019 р. у справі № 826/9285/17. URL: http://www.reyestr.court.gov.ua/Review/86305757 (дата звернення : 06.03.2020).

19 Шевчук С. Основи конституційної юриспруденції. Харків: Консум, 2002. 296 с. С. 206.

20 Про внесення змін до постанови Кабінету Міністрів України від 10 вересня 2014 р. № 442: постанова Кабінету Міністрів України № 591 від 05 липня 2015 р. Офіційний вісник України. 2015. № 66, ст. 2182.

21 Про судове рішення в адміністративній справі: постанова Пленуму Вищого адміністративного суду України № 7 від 20 травня 2013 p. URL: https://zakon.rada.gov.ua/laws/show/v0007760-13 (дата звернення : 06.03.2020). п.10.2.

22 Про внесення змін до постанови Кабінету Міністрів України від 10 вересня 2014 р. № 442: постанова Кабінету Міністрів України № 591 від 05 липня 2015 року. Офіційний вісник Украӥни. 2015. № 66. Ст. 2182.

23 Про судове рішення в адміністративній справі: постанова Пленуму Вищого адміністративного суду України № 7 від 20 травня 2013 p. URL: https://zakon.rada.gov.ua/laws/show/v0007760-13 (дата звернення : 06.03.2020). п. 10.2.

24 Деякі питання Державної санітарно-епідеміологічної служби: постанова Кабінету Міністрів України № 348 від 29 березня 2017 р. Офіційний вісник Украӥни. 2017. № 43. Ст. 1329. п. 3.

25 Про затвердження тимчасових методичних рекомендацій «Епідеміологічний нагляд і контроль за випадками пташиного грипу у людей»: наказ Міністерства охорони здоров’я України № 341 від 19 червня 2007 p. URL: http://mozdocs.kiev.ua/ view.php?id=8933

26 Про затвердження Переліку інфекційних захворювань: наказ Міністерства охорони здоров’я України № 362 від 13 квітня 2016 р. Офіиійний вісник України. 2016. № 45. Ст. 1654.

27 Про затвердження Порядку проведення епідеміологічного нагляду за кором, краснухою та синдромом вродженої краснухи: наказ Міністерства охорони здоров’я України № 954 від 23 квітня 2019 р. Офіиійний вісник Украӥни. 2019. № 45. Ст. 1570.

28 Про затвердження Порядку організації проведення епідеміологічного нагляду за грипом та гострими респіраторними вірусними інфекціями, заходів з готовності в міжепідемічний період і реагування під час епідемічного сезону захворюваності на грип та ГРВI: наказ Міністерства охорони здоров’я України № 1126 від 17 травня 2019 р. Офіиійний вісник України. 2019. № 51. Ст. 1762.

29 Decision No 1082/2013/EU of the European Parliament and of the Council of 22 October 2013 on serious cross-border threats to health and repealing Decision No 2119/98/EC Text with EEA relevance. OJ L 293, 5.11.2013. P. 1-15. art. 3.

30 Проєкт Закону про внесення змін до Закону України «Про забезпечення санітарного та епідемічного благополуччя

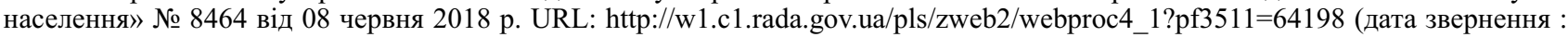
06.03.2020).

31 Про забезпечення санітарного та епідемічного благополуччя населення: Закон України № 4004-XII від 24 лютого 1994 р. (зі змінами). Відомості Верховної Ради України. 1994. № 27. Ст. 218. ч. 1, ст. 39.

32 Про затвердження Положення про державний санітарно-епідеміологічний нагляд в Україні: постанова Кабінету Міністрів України № 1109 від 22 червня 1999 р. (зі змінами). Офіиійний вісник Украӥни. 1999. № 25. Ст. 1178.

33 Про затвердження Положення про Державну службу України з питань безпечності харчових продуктів та захисту споживачів: постанова Кабінету Міністрів України № 667 від 02 вересня 2015 р. (із змінами). Офіційний вісник Украӥни. 2015. № 73. Ст. 2402.

34 Про забезпечення санітарного та епідемічного благополуччя населення: Закон України № 4004-XII від 24 лютого 1994 р. (із змінами). Відомості Верховної Ради України. 1994. № 27. Ст. 218. ч. 2, ст. 39.

35 Там само. п. й ч. 1 ст. 40.

36 Положення про Міністерство охорони здоров’я України: затверджено постановою Кабінету Міністрів України № 267 від 25 березня 2015 р. (зі змінами). Офіиійний вісник України. 2015. № 38 (22.05.2015). Ст. 1141. п.п.14, п. 4.

37 Про забезпечення санітарного та епідемічного благополуччя населення: Закон України № 4004-ХІІ від 24 лютого 1994 р. (зі змінами). Відомості Верховної Ради Украӥни. 1994. № 27. Ст. 218. ч. 2, ст. 39.

38 Там само. абз. 6, ст. 33.

39 Там само. абз. 13, ст. 1.

40 Там само. ч. 2 , ст. 36

41 Про забезпечення санітарного та епідемічного благополуччя населення: Закон України № 4004-XII від 24 лютого 1994 р. (із змінами). Відомості Верховної Ради Украйни. 1994. № 27. Ст. 218. ст. 42.

42 Там само.

43 Про затвердження Положення про Державну службу України з питань безпечності харчових продуктів та захисту споживачів: постанова Кабінету Міністрів України № 667 від 02 вересня 2015 р. (із змінами). Офіційний вісник Украӥни. 2015. № 73. Ст. 2402.

44 Мірошніченко А.М. Колізії в правовому регулюванні земельних відносин в Україні. 2-ге вид., перероб. і допов. Київ: Алерта; КНТ; ЦУЛ, 2010. 270 с. С. 210.

45 Положення про Міністерство охорони здоров’я України: затверджено постановою Кабінету Міністрів України № 267 від 25 березня 2015 р. (із змінами). Офіиійний вісник України. 2015. № 38. Ст. 1141. п.п. 1, 3.

46 Белей Є.Н. Контроль і нагляд у сфері громадського здоров'я. Вчені записки ТНУ імені В.І. Вернадського. 2018 . № 5. Т. 29 (68). С. 41-48. С. 44 (Серія «Юридичні науки»).

47 Про схвалення Концепції розвитку системи громадського здоров'я: розпорядження Кабінету Міністрів України № 1002-р від 30 листопада 2016 р. Офіційний вісник Украӥни. 2017. № 1. Ст. 21.

48 Про утворення державної установи «Центр громадського здоров’я Міністерства охорони здоров'я України»: наказ Міністерства охорони здоров'я України № 604 від 18 вересня 2015 р. (з змінами). URL: https://zakon.rada.gov.ua/rada/show/ v0604282-15 (дата звернення: 06.03.2020).

49 Про деякі питання реорганізації державних підприємств та установ МОЗ України: наказ Міністерство охорони здоров’я України від 03 листопада 2017 р. № 1363. URL: https://ips.ligazakon.net/document/view/MOZ28091 (дата звернення : 06.03.2020).

50 Статут Державної установи «Центр громадського здоров'я Міністерства охорони здоров'я України»: затверджений наказом Міністерства охорони здоров’я України № 515 від 20 березня 2018 p. URL: https://phc.org.ua/sites/default/files/uploads/ files $/ \mathrm{C} \% \mathrm{D} 1 \% 82 \% \mathrm{D} 0 \% \mathrm{~B} 0 \% \mathrm{D} 1 \% 82 \% \mathrm{D} 1 \% 83 \% \mathrm{D} 1 \% 82 \% 20 \% \mathrm{D} 0 \% \mathrm{~A} 6 \% \mathrm{D} 0 \% 93 \% \mathrm{D} 0 \% 97 \% 202018$.pdf (дата звернення: 06.03.2020).

51 Проневич О.С. Імплементація Регламенту (СС) 851/2004 про утворення Європейського центру з профілактики та контролю за захворюваннями: стан, проблеми і перспективи. Право і безпека. 2017. № 3 (66). С. 45-51. С. 47.

52 Нізова Н.М. Поточні виклики для Державної установи «Центр громадського здоров'я Міністерства охорони здоров'я України. Україна. Здоров’я націï. 2017. № 3(44). С. 331-332. С. 332. 
53 Проневич О.С. Імплементація Регламенту (СС) 851/2004 про утворення Свропейського центру з профілактики та контролю за захворюваннями: стан, проблеми і перспективи. Право і безпека. 2017. № 3 (66). С. 45-51. С. 49.

54 Про центральні органи виконавчої влади: Закон України № 3166-VI від 17 березня 2011 р. Офіиійиний вісник Украӥни. 2011. № 27. Ст. 1123. ч. 1, ст. 5.

55 Актуальність створення Національного центру громадського здоров'я та контролю за захворюваннями. Аналітичний звіт. Драфт. Серпень 2015 року. URL: http://www.hivreforminaction.org/wp-content/uploads/2015/10/National-Public-Health-andDisease-Control-Center-draft.pdf (дата звернення: 06.03.2020).

56 Про затвердження Положення про Державну службу України з питань безпечності харчових продуктів та захисту споживачів: постанова Кабінету Міністрів України № 667 від 02 вересня 2015 року (з змінами). Офіційний вісник Украӥни. 2015. № 73. Ст. 2402 .

\section{Резюме}

\section{Демченко І.С. Інституційна спроможність захисту від інфекційних захворювань в Україні.}

У статті досліджується питання інституційної спроможності (системи та повноважень) органів державної влади у сфері забезпечення санітарного та епідемічного благополуччя населення. Аналізується процес реорганізації та ліквідації державної санітарно-епідеміологічної служби України. Розглядається процедура передачі повноважень державної санітарно-епідеміологічної служби України до Держпродспоживслужби та Міністерства охорони здоров'я України. Досліджуються колізії у законодавстві щодо епідеміологічного нагляду. Пропонуються шляхи посилення інституційної спроможності захисту від інфекційних захворювань в Україні.

Ключові слова: санітарно-епідеміологічний нагляд; інфекційні захворювання; охорона здоров'я; населення.

\section{Резюме}

Демченко И.С. Институциональная способность защиты от инфекционных заболеваний в Украине.

В статье исследуется вопрос институциональной способности (системы и полномочий) органов государственной власти в сфере обеспечения санитарного и эпидемического благополучия населения. Анализируется процесс реорганизации и ликвидации государственной санитарно-эпидемиологической службы Украины. Рассматривается процедура передачи полномочий государственной санитарно-эпидемиологической службы Украины в ведение Государственной службы по вопросам безопасности продовольственных продуктов и защите прав потребителей и Министерства здравоохранения Украины. Исследуются коллизии в законодательстве относительно эпидемиологического надзора. Предлагаются пути усиления институциональной способности защиты от инфекционных заболеваний в Украине.

Ключевые слова: санитарно-эпидемиологический надзор; инфекционные заболевания; здравоохранение; населения.

\section{Summary}

Ivan Demchenko. Institutional capacity on protection against infectious diseases in Ukraine.

The reform of sanitary and epidemiological surveillance and protection of the population against infectious diseases is accompanied by serious challenges and unforeseen circumstances. In Ukraine, a significant number of persons who are infected with hepatitis $\mathrm{C}$ and B. Ukraine is a leader in Europe in terms of HIV prevalence. In 2019, half of all measles cases in the European Region were reported in Ukraine. In the same year, the number of cases of diphtheria increased. In Ukraine, a significant number of tuberculosis patients. Coronavirus (COVID-19) is spreading worldwide today. In this article, we will focus on issues Institutional capacity on protection against infectious diseases in particular, and sanitary-epidemiological surveillance in particular.

The Ministry of Health of Ukraine is the central executive authority, which provides formation and implementation of the state policy on protection of the population health against infectious diseases. The Ministry of Health of Ukraine also ensures the formation of state policy in the areas of sanitary and epidemiological well-being of the population.

What executive authority implements the state policy in the sphere of sanitary and epidemiological well-being of the population, regarding the protection of the population from infectious diseases? This authority was the State Sanitary and Epidemiological Service of Ukraine (SES). In 2014, the Cabinet of Ministers of Ukraine decided to reorganize the SES. The decision on the reorganization of the SES was appealed in court and was found unlawful. In 2017, the Cabinet of Ministers of Ukraine changed its previous decision now the SES was not subject to reorganization but liquidation. In terms of unlawfulness / lawfulness of actions (decision-making) by the Cabinet of Ministers of Ukraine were analyzed. The conclusion: Cabinet of Ministers had been acted in full compliance with the requirements of the legislation.

An analysis of the history of the delegation of powers of the SES (including the results of court proceedings in this case) shows that: the functions of the implementation of state policy that belonged to the SES were entrusted to the State Service on Food Safety and Customer Protection, without functions of the implementation of state policy in the field of epidemiological surveillance.

The problem is that, term what is "epidemiological surveillance", at least at the legislative level is not set. At national legislation is enshrined and detailed in the subordinate legal acts "state sanitary and epidemiological surveillance". It is justified that the transfer of the powers of the SES was not carried out properly and, in fact, its powers are not assigned to any of the state authorities.

Key words: sanitary and epidemiological surveillance; infectious diseases; prevention; public health; population. 